\title{
Correction to: Development of a genetic evaluation for hair shedding in American Angus cattle to improve thermotolerance
}

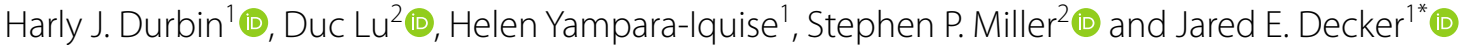

\section{Correction: Genet Sel Evol (2020) 52: 63} https://doi.org/10.1186/s12711-020-00584-0

In Durbin et al. [1], the correlation between partial and full breeding values, $\rho_{p, w}^{v}$, was reported as a measure of prediction accuracy, which is not correct; the metric $\rho_{p, w}^{v}$ is the ratio between prediction accuracy in the partial dataset and prediction accuracy in the whole dataset. We have now calculated accuracy as follows:

$$
\widehat{\operatorname{ccc}}_{L R}=\sqrt{\frac{\operatorname{cov}\left(\hat{u}_{w}, \hat{u}_{p}\right)}{(1-\bar{F}) \hat{\sigma}_{u}^{2}}},
$$

where cov is the covariance and $\bar{F}$ is the average inbreeding coefficient of the animals in the partial dataset. The equation for $\widehat{a c c}_{L R}$ is adapted from [2].

Across the 10 cross-validation iterations, the average accuracy was $\widehat{a c c}_{L R}=0.547$ (minimum $=0.539$, maximum $=0.554)$.

\section{Acknowledgements}

We appreciate Daniela A.L. Lourenco and Ignacy Misztal for helping us identify and correct this error.

\author{
Author details \\ ${ }^{1}$ University of Missouri, Columbia, MO 65211, USA. ${ }^{2}$ Angus Genetics Inc., St. \\ Joseph, MO 64506, USA.
}

Published online: 22 March 2021

\section{References}

1. Durbin HJ, Lu D, Yampara-lquise H, Miller SP, Decker JE. Development of a genetic evaluation for hair shedding in American Angus cattle to improve thermotolerance. Genet Sel Evol. 2020;52:63. https://doi.org/10. 1186/s12711-020-00584-0.

2. Macedo FL, Reverter A, Legarra A. Behavior of the linear regression method to estimate bias and accuracies with correct and incorrect genetic evaluation models. J Dairy Sci. 2020;103:529-44.

\section{Publisher's Note}

Springer Nature remains neutral with regard to jurisdictional claims in published maps and institutional affiliations.

(c) The Author(s) 2021. This article is licensed under a Creative Commons Attribution 4.0 International License, which permits use, sharing, adaptation, distribution and reproduction in any medium or format, as long as you give appropriate credit to the original author(s) and the source, provide a link to the Creative Commons licence, and indicate if changes were made. The images or other third party material in this article are included in the article's Creative Commons licence, unless indicated otherwise in a credit line to the material. If material is not included in the article's Creative Commons licence and your intended use is not permitted by statutory regulation or exceeds the permitted use, you will need to obtain permission directly from the copyright holder. To view a copy of this licence, visit http://creativecommons.org/licenses/by/4.0/. The Creative Commons Public Domain Dedication waiver (http://creativecommons.org/publicdomain/zero/1.0/) applies to the data made available in this article, unless otherwise stated in a credit line to the data. 